\title{
Insider Privatization and Careers - A Clinical Study of a Russian Firm in Transition*
}

\author{
Guido Friebel ${ }^{\dagger}$ and Elena Panova ${ }^{\ddagger}$
}

March 2006

\begin{abstract}
Transition provides an unexplored opportunity to study how changes in ownership affect structure and human resource policies of firms. We investigate a unique data set (17 years, 1500 white collar workers) of a Russian insider-privatized firm. In contrast to conventional beliefs about insider-privatized firms, there is much evidence for restructuring. However, the firm becomes "toploaded". There is massive hiring from the outside, in particular, for higher tiers in the hierarchy. As there is also less exit, in particular, from higher levels, previously existing career paths are blocked. This potentially distorts the incentives for investment in firm-specific human capital. We argue that weak property right enforcement may be the reason for our observations, and thus identify a novel channel through which institutions may affect firm efficiency.
\end{abstract}

Keywords: Internal labor markets, restructuring, personnel files

JEL Classification Codes: M50, P31, J41

\footnotetext{
${ }^{*}$ We would like to thank for helpful discussions: Erik Berglöf, Anders Björklund, Peter Gottschalk, Joep Konings, Margaret Meyer, Åsa Rosén, Kathy Terrell and seminar participants at Boston College, LICOS Leuven, London Business School, SITE (Stockholm School of Economics), SOFI (Stockholm University), University of Michigan, and the University of Toulouse. We are grateful for the support of SITE. All errors are ours.

${ }^{\dagger}$ University of Toulouse (EHESS and IDEI), CEPR and IZA. Email: friebel@cict.fr

${ }^{\ddagger}$ University of Toulouse. Email: e_panova@yahoo.com
} 


\section{Introduction}

How do firms adjust their internal structure to changes in their economic and institutional environment? Chandler (1977) has investigated how firms in the last century adjusted to challenges posed by new technologies and the market by developing professional management, the line/staff and later the multidivisional organization. Doeringer and Piore (1971) have documented how and why firms created internal labor markets to protect their workers from market shocks and to provide them with incentives to invest in firmspecific human capital. Following the studies of Carter and Carter (1985), Baker, Gibbs and Holmström (1994), and Lazear (1992), a large literature of case studies of internal labor markets has emerged. ${ }^{1}$ These studies investigate the personnel files of single firms over a long period of time to learn more about how firms design their internal structure, career paths and wage policy, and how these adjust to changes in the environment. One main finding is that the internal structure of firms is remarkably stable, even in turbulent times. In particular, firms do rarely change their career paths.

Transition provides a unique field of experimentation to learn more about the adjustment of firms to outside shocks. Transition is a particularly drastic shock, a process of large-scale institutional and structural change that confronts firms with challenges they have to adapt to in a short period of time. Djankov and Murrell (2001) summarize the literature on enterprise restructuring in transition economies. This literature measures the impact of reform variables such as privatization, the hardening of budget constraints, increasing competition, and price liberalization on enterprise performance. One important finding is that while both state-owned and insider-privatized firms show little signs of restructuring, firms that are privatized to outsiders are more likely to improve their performance. This fact is particularly significant when foreigners are involved.

The literature does, however, not tell us much about the micro channels

\footnotetext{
${ }^{1}$ An incomplete list includes: Ariga et al (1999), Dohmen (2004) and Dohmen et al (2004), Ichino (1999), Seltzer and Merret (2000), Treble et al (2001).
} 
through which changes in the environment affect enterprise performance. Put differently, transition economics treats firms as "black boxes". In this paper, we open the black box of a firm in transition. We carry out an indepth "clinical study" 2 using a unique personnel data set from a Russian heavy industry firm that was privatized in 1993. The data set covers a total of around 1500 white-collar individuals over a maximum of 17 years, from 1984 to 2000. Our paper, first, documents the changes in the internal structure and career paths of the firm and carries out a duration analysis on the determinants of promotions and exits before and after insider-privatization. Second, our observations lead us to identify a new channel through which institutions, in particular, weak protection of property rights, may affect the internal structure of firms and their efficiency.

We observe the following: First, prior to transition, that is, until 1992, the firm featured stable patterns of upward mobility that look very similar to the career paths in western firms. ${ }^{3}$ Second, while most other studies identify little evidence for behavioral change of firms after insider privatization, we find strong micro-evidence for restructuring activities. The employment of blue collar workers decreases substantially and its correlation with output changes appears to increase. The number of white collar workers and managers is remarkably stable. Moreover, there is a substantial reallocation of the wage bill from blue to white collar and managerial staff. Grosfeld and Roland (1999) have phrased the distinction between defensive (costcutting) and strategic restructuring. ${ }^{4}$ In the case of the firm we look at, it appears that the defensive restructuring part has mainly affected blue collar workers, while white collar workers seem to be protected. Third, there are also signs for strategic restructuring. White collar workers are shifted across

\footnotetext{
${ }^{2}$ For a short discussion on the role of clinical studies in finance, see Journal of Financial Economics (1989).

${ }^{3}$ This may seem surprising. However, in a way similar to western firms, Soviet firms made use of promotions as main instrument to incentivize and, in particular, retain their workers. The main difference between Soviet and western firms is not so much the use of promotions, but rather the fact that in Soviet firms, promotions provided access to additional fringe benefit, rather than substantial wage increases (see Kornai, 1992).

${ }^{4}$ For a moel on defensive and strategic restructuring of insider-privatized firms see Debande and Friebel (2004).
} 
functions within the firm. Most importantly, the firm hires massively from the outside, in particular, for higher tiers in the hierarchy.

Fourth, the firm becomes "toploaded". Both descriptive statistics and a duration analysis show that after privatization, the patterns of promotion and exit change, in particular, upward mobility from lower levels in the hierarchy decreases. In a nutshell, it appears that the career paths that existed prior to privatisation are blocked, because incumbents do not leave and more managers are hired from the outside market.

This change in the career paths of the firm may have adverse consequences on the efficiency of the firm. As Gibbons and Waldman (1999) document, career prospects are among the most important instruments for incentivizing employees to invest in firm-specific human capital. In the absence of long-term career opportunities these incentives may decrease and induce high turnover on lower levels of the white collar hierarchy. Thus, while Baker, Gibbs and Holmstrom (1994) and many other studies found remarkable stability in the way the firm operated its internal labor market, the stable patterns of upward mobility that the firm exposes prior to transition appear to be destroyed after transition.

We interpret these observations as follows. In Russia, outsiders receive little or no protection of their property rights. ${ }^{5}$ The incumbent managers became owners when the firm was privatized. They hired new managers from the outside labor market with skills that are more adapted to a market economy. But, the incumbent manager-owners stay, because they can only assure their property rights by remaining inside-owners. The consequence of this is the blockage of career paths that we document.

In principle, this type of inefficiency could be overcome by selling the firm to the newly hired managers. However, this is not an option in Russia. Banks are not willing to lend individuals money to acquire shares of the firm, as outside ownership rights are only weakly enforced. The firm is thus stuck in a situation in which new and old managers occupy higher positions and in which internal labor market practices such as career paths become unfeasible. This has potentially adverse effects, for instance, suboptimal

\footnotetext{
${ }^{5}$ This is one of the most notorious facts of the Russian economy. See, for instance Woodruff (2004).
} 
human capital investment and excessive turnover on lower levels. We discuss these points further in the concluding section of the paper.

\section{The firm and its environment}

We investigate 17 years (1984-2000) of personnel data of one of the largest enterprises in the machinery industry in Russia. The enterprise was established in 1949. Prior to transition it was one of the leading companies in the industry and was awarded a number of distinctions. In March 1993, the firm was privatized through the so-called option 2 of the Russian voucher privatization, which provided privileges to insider workers and managers in acquiring shares. Since then, it has been a joint stock company. The annual report for 1997 indicates about 92\% individual ownership. A total of $53.4 \%$ of the firm is owned by insiders, but we have no information about individual shareholdings or the distribution between managers and workers. Neither municipality nor the regional government own shares, and there is no foreign capital. According to our interviews with managers in the firm, non-managerial employees delegate their votes to the manager of their department. As a consequence of this proxy voting, the firm is effectively controlled by a small number of managers. Nonetheless, managers must take into account the interest of the worker shareholders, who can revoke the proxy right. We will later argue that this specific arrangements may explain some of the features that we observe in the firm.

Figure 1 (Appendix) provides an overview of how output and employment of the firm changed, plotted against major events in the eighties and nineties. The firm went through a first output decline in 1987 when it had to cope with Gorbachev's "perestroyka”. Decentralization of decision-making power damaged some of the traditional supply channels and affected demand. Since that time, and until 1997, employment has declined. There is a steep drop in output from 1992 onwards, which is typical for these years, in particular, for heavy industry. From 1997, we note a positive tendencey, and in 1999, the enterprise won a tender to supply equipment to India.

Figure 2 shows that there is an important correlation between total output and the main five items of production of the firm (heavy machinery). 
At different points in time, the firm experimented with new product lines, for instance, tailor-made instruments. It has also, in the late 90's cut down the production of consumer (plastic) goods, the production of which was commenced in the late 1980's in the Gorbachev era.

Figure 3 looks in a more detailed way into the linkage between output changes and employment. It appears that employment is sensitive to output changes, although it reacts with a lag. After privatization (1993), the sensitivity of employment to output appears to increase. Figure 4 shows that industrial employment, that is, workers employed in the core operations of the firm, has steadily declined throughthe nineties. ${ }^{6}$ Figure 5 shows that through this period of time, the ratio between white and blue collar workers has increased; mainly blue collar jobs have been shed.

We do not dispose of information about individual wages, but we do know the so-called "wage fund". This total wage bill also includes wage arrears and in-kind payments. Figure 6 shows that since the firm got privatized, a clear reallocation of the wage bill from blue to white-collar workers has occured. Whether this reflects changes in productivity that come along with transition, a shift of demand, or a shift of power within the firm, we do not know.

Summarizing, one can state the following: First, the firm shrinks until 1996, and grows afterwards. Second, employment becomes more responsive to output changes after privatization. Third, the firm's growth is highly correlated with its core business. Fourth, labor shedding mainly affects blue collar workers. Fifth, the wage bill is reallocated from blue to white collar workers.

\section{The "internal economics" of the firm}

We here investigate the personnel files of the firm to track down potential changes after privatization. We are looking at the following things: First, how does the firm allocate its human resources across job titles, before

\footnotetext{
${ }^{6}$ Similar to many other large industrial firms in Russia, the firm employed a large number of employees in non-industrial activities such as restaurants, hospitals, kindergartens, and housing.
} 
and after privatization, and how does hiring from the outside labor market change? Second, how does upward intra-firm mobility (careers) change? ${ }^{7}$ We start with describing the data and our approach of analysis.

\subsection{Data}

We use the raw data from the human resource department of the firm. There is one personnel file for each individual in the firm. This file contains information about: entry, exit date, dates of movements across job titles, an occupational code for each position that is defined by Goskomstat, the statistical office of Russia. Moreover, we know the affiliation of an individual within the firm, whether they work in production, engineering, administration (sales, planning, accounting) or in other services, for instance, the human resource department. Moreover, there is data on personal characteristics: age, education, gender, place of birth, place of university education, field of study, party and trade union membership, ethnicity, marital status, number of children. We also know about the job history of an individual: military service, date of leaving previous job, last employer.

In total, we have the data of roughly 1500 white-collar employees. Notice that, in principle, we only look at white collars and management positions. However, there are a number of people who moved from blue-collar to whitecollar and managerial positions (sometimes also back). Hence, the job title "blue collar" also appears. We took out individuals that are not working in the core business of the firm, for instance, restaurant and kindergarten personnel.

We proceed in a way similar to Baker, Gibbs and Holmstrom (1994) who construct the hierarchy of the firm by looking at the proportion of human resources that the firm uses on different job titles and the flows between these titles. The algorithm to compute "persondays per title" is very simple. Consider any given individual whose date and job title of entry we know. We also know for how long a person stayed on a given job title, before being promoted, demoted, moving laterally or exiting. For each job title, we can

\footnotetext{
${ }^{7}$ We do not look at downward mobility, because it is, as in many other studies, harder to interpret. In particular, in Russia, retirees often remain in the firm, at lower positions in the hierarchy.
} 
then add up the persondays over individuals. These persondays per title can be expressed as a ratio of the total human resources in the firm.

Our main interest is how transition, in particular, the firm's privatization has changed its human resource policies - entry, exit and mobility within the firm. Thus, we will cut our observation in two parts: the period 1984 to 1991 , and the period 1992 to 2000, that is after privatization. Any statements about the effect of transition (or privatization) relate to a comparison of these two periods.

\subsection{Allocation of human resources across job titles, hiring and staffing from within}

As in other related work (for instance, Baker, Gibbs and Holmström, 1994), human resources are concentrated on few job titles. In our case, twelve job titles on five levels represent close to $90 \%$ of total white collar staff. We hence focus on these job titles.

Table 1 shows the allocation of total human resources across these job titles. On level 0, we find blue-collar workers. As explained before, these are blue collars who at some stage in their career moved up into white collar or managerial positions. We indicate this title only for completeness. The five levels for white-collar and managerial workers are: Level 1, comprising different types of technicians and accountants. Level 2 employees are economists, planning engineers, engineers or foremen, a managerial position in production. Level 3 entails head of bureau, the responsible of a nonproduction unit, and supervisor, the respective equivalent in a production unit. On level 4, we find the heads of production and non-production departments; level 5 is top management. The columns "persondays" show how the firm allocates its human resources before and after transition, expressed as the ratio of persondays per title over total persondays in the firm, in the respective period of time.

Comparing these columns we see that the firm has changed its use of human resources. It has shifted from production-oriented job titles (technician, engineer) to job titles that are related to business administration (accountant, economist) and R\&D (planning technician and planning engi- 
neer). Moreover, we notice that more of the human resources is concentrated in the higher echelons of the firm (levels 3 and 4).

Table 3 presents entry data for jobs on different levels. The main observation is that transition does not much affect entry to jobs on level 2: the proportion of people who enter from the outside market after transition is similar to the respective proportion before transition. However, for higher levels, the firm increases its hiring activity from the outside labor market after transition, and reduces staffing from the inside of the firm.

\subsection{Internal mobility: career paths}

From our data set it is straightforward to create a transition matrix to capture movements across job titles and exits from the firm. Figure 7 illustrates these transitions between titles, here the show upward mobility prior to transition. The numbers indicate the probability of a person who holds job title $i$ to move to title $j$. We here plot links between job titles that have a transition probability of at least $5 \%$. Prior to transition, the firm maintained a couple of career paths, some of them leading to the very top of the company. This is very similar to the picture that Baker, Gibbs and Holmström (1994) find for a large western firm. Notice that the probabilities to move from blue-collar to any other position are contingent on the individual holding a white-collar or managerial job at some point in their career. They do not represent the odds of any blue collar worker to move up in the hierarchy.

Figure 8 shows that after transition, there is more upward mobility between lower tiers in the hierarchy, but it becomes more or less impossible to move upward from level 2. The previously existing career paths appear to be blocked.

Taking together these observations and the ones from the previous section, the following picture emerges. After transition, the firm hires people for higher levels in the hierarchy mainly from the outside market, rather than staffing these positions from within. This hiring from the outside world coincides with more demotions from level 4. More importantly, upward mobility and thus, career paths, become roadblocked: it becomes very hard for anyone to reach level 3 or higher in the firm. 


\subsection{Duration analysis: promotion and exit}

The descriptive statistics in the preceding section indicate that there have been changes in upward mobility patterns after transition. In order to learn more about these patterns and their determinants, we have carried out a duration analysis on two events: a) promotion to level 3 or higher, b) exit from the firm. (Naturally, we cannot run any regressions on entry.)

As much of what we do is standard in labor economics (see Van den Berg, 2001), we here only briefly comment on the method. First, we split the time span into two intervals of similar length (from 1984 to 1991 and from 1992 to 2000). ${ }^{8}$ We then run two regressions for the events "promotions" and "exits" for each interval. We apply an accelerated failure time model ${ }^{9}$ in which the natural logarithm of the survival time $t$ is assumed to be linearly dependent on covariates:

$$
\ln \left(t_{j}\right)=x_{j} \beta+\epsilon
$$

with $x_{j}$, a covariate vector, $\beta$, a vector of regression coefficients, and $\epsilon$, an error term with density $f(\cdot)$. For our regressions, we look at three basic individual characteristics - age, gender, and education as covariates. ${ }^{10} \mathrm{We}$ enrich this set by including the level variable when looking at exits. We assume that the density of the error term follows a generalized Gamma model:

$f(t)=\left\{\begin{array}{c}\frac{|\kappa|}{\Gamma\left(\frac{1}{\kappa^{2}}\right)} \cdot\left(\frac{1}{\kappa^{2}}\right)^{\frac{1}{\kappa^{2}}} \cdot \exp \left[\frac{1}{\kappa^{2}} \cdot\left(\kappa \frac{\ln (t)-x \beta}{\sigma}-\exp \left(\kappa \frac{\ln (t)-x \beta}{\sigma}\right)\right)\right], \text { if } \kappa \neq 0 \\ \frac{1}{\sqrt{2 \pi}} \cdot \exp \left(-\frac{(\ln (t)-x \beta)^{2}}{2 \sigma^{2}}\right), \text { if } \kappa=0\end{array}\right.$

with $\kappa$ and $\sigma$, ancillary parameters to be estimated from the data (see Kalbfleish and Prentice, 1980). The hazard function of the generalized Gamma distribution is highly flexible. ${ }^{11}$ It should be noted that signs and

\footnotetext{
${ }^{8}$ We start our observations at 1984 controlling for the exact entry date for those individuals who were hired before this year.

${ }^{9} \mathrm{~A}$ statistical test based on the distribution of Schoenfeld residuals rejected the often used Cox proportional hazard model.

${ }^{10}$ Our results in this specification are robust. Only these three variables appear to be significant and have the same sign in all possible regressions we tried.

${ }^{11}$ The Wald likelihood ratio test rejected the hypothesis of a Weibull distribution $(\kappa=$ $1)$.
} 
significance of estimated parameter are robust, while the magnitude of effects cannot be interpreted.

Table 4 looks at the determinants of promotion to level 3 or higher. Notice that the signs of parameters must be interpreted inversely: negative signs mean that the respective variable increases the probability of being promoted (or, to exit). One star stands for significance at $10 \%$ level, two stars at $5 \%$ level. Things seem to change: prior to transition, promotion was more likely for younger individuals or individuals with better education. After transition these variables lose their statistical significance. Notice also that the incidence of promotions has decreased drastically from more than 150 to 64 , while the number of individuals in the two periods is more or less constant.

Table 5 presents the determinants of exit from the firm. The high number of exits is owing to the fact that an individual that exits at $t=0$ is treated as an exit for all following periods. While we can say little about changing determinants of exit, it becomes evident that exit rates fall massively, after transition (from around 1700 to 300 observations).

The picture becomes clearer when one plots the hazard rates of promotion and exits that are implied by our regressions. Prior to transition the hazard rates concerning promotion where increasing over time, while after transition, this is not the case. Even more striking, the exit rates that our estimations imply decrease: after transition, they are barely different from zero, except for workers with very short tenure in the firm.

\section{Concluding discussion: the role of property right enforcement}

Our firm shows evidence for restructuring: it concentrates on core activities and sheds blue collar jobs. It shifts the use of human resources from production to administrative and management activities, and hires from the outside world, in particular for higher levels. Promotion and exit rates fall. This has the interesting effect that the firm becomes toploaded. Career paths that existed in the firm are blocked, which may have potentially adverse 
effects for the motivation of the workers in the firm. If making a career in a firm is the main incentive device to invest into firm-specific human capital, the fact that career paths are closed because of outside hiring distorts these incentives, and may, in the medium run, harm the firm. Moreover, the firm will find it hard to retain the best workers or attract new capable workers.

Two elements seem to be responsible for blocking career paths. First, the firm hires from the outside world, second, the incumbent managers do not exit. With respect to the first cause, there is not much that the firm can do: Strategic restructuring is only partially possible by reassigning workers within the firm. Outside hiring is required to satisfy the changing human capital needs of the firm. Moreover, in transition, labor markets liberalize, labor shortage disappears and workers begin to move. The labor market becomes thicker after transition, making it possible for the firm to hire new workers and managers that have the skills the firm needs.

Thus it would be hardly imaginable that the firm would want to forego these hiring opportunities in order to be able to maintain career paths. However, it appears that there is a simple remedy for the problem: In order to open up career paths again, managers and workers on different levels in the firm should leave, freeing space for lower-level workers and opening up career paths.

Why do managers not leave the firm? We believe that what makes them stay in the firm is a particularity of Russia, and other transition and development countries: weak protection of property rights. Higher-level managers own shares in the company. Russian firms are notorious for their attempts to expropriate outside owners. In order to ensure that cash flow rights are respected, managers may thus decide to stay in the firm, although they lack the human capital needed to operate in a market economy. Moreover, they block the career paths of more junior workers. For similar reasons, it may be hard for managers to buy out the incumbent managers. Banks are usually not willing to give loans if the only collateral are company assets that are hard to be seized.

Blaming the peculiarities of privatisation in Russia for the above observations is also consistent with the fact that it is mostly blue-collar jobs that are destroyed in the firm, and the fact that the wage bill is reallocated from 
blue to white-collar workers. As pointed out, shareholdings are dispersed in the firm, but workers delegate their voting rights to the top levels in the firm. White collars usually hold more shares and thus constitute a more powerful group in the firm. They are also better informed, and have closer links to the people taking decisions. Managers thus appear to be more inclined to cater to their interests then to the one of blue collar workers.

Although we look at only one firm and can hence not claim generality, we believe that our case study may help to better understand the adjustment processes of firms in economies with weak institutions. Clinical studies like ours can help in suggesting interpretations when representative econometric analysis is unavailable. They can also help to stimulate theoretical work; here, about the influence of institutions on the internal functioning of firms. Our paper points to a new channel through which property right enforcement may affect firm efficiency: by imposing constraints on the internal structure of firms and its human resource policies.

\section{References}

[1] Ariga, Kenn, Yasushi Ohkusa, and Giorgio Brunello (1999), "Fast Track: Is it in the Genes? The Promotion Policy of a Large Japanese Firm," Journal of Economic Behavior and Organization 38: 385-402.

[2] Baker, George, Michael Gibbs and Bengt Holmstrom (1994), "The Internal Economics of the Firm: Evidence from Personnel Data", Quarterly Journal of Economics 109: 881-919.

[3] Carter, Michael and Susan Carter (1985), "Internal Labor Markets in Retailing: The Early Years", Industrial and Labor Relations Review 38: 586-98.

[4] Chandler, Alfred D. (1977), The Visible Hand: The Managerial Revolution in American Business, Cambridge, Mass: Harvard University Press. 
[5] Debande, Olivier and Guido Friebel (2004), "A Positive Theory of Insider-privatization", forthcoming in International Journal of Industrial Organization.

[6] Djankov, Simeon and Peter Murrell (2002), "Enterprise Restructuring in Transition: A Quantitative Survey", Journal of Economic Literature 40: 739-92.

[7] Doeringer, Peter and Michael Piore (1971), Internal Labor Markets and Manpower Adjustment. Lexington, Mass: D.C. Heath.

[8] Dohmen, Thomas (2004), "Performance, Seniority and Wages: Formal Salary Systems and Individual Earnings Profiles", Labour Economics 11: $741-763$.

[9] Dohmen, Thomas, Ben Kriechel and Gerard A. Pfann (2004), "Monkey Bars and Ladders: The Importance of Lateral and Vertical Job Mobility in Internal Labor Market Careers", Journal of Population Economics 17: 193-228.

[10] Gibbons, Robert and Michael Waldman (1999), "Careers in Organizations: Theory and Evidence", in Handbook of Labor Economics, ed. by Orley C. Ashenfelter, and David Card, vol. 3B, pp. 2373-2437, Amsterdam, The Netherlands. Elsevier Science.

[11] Grosfeld, Irena and Gerard Roland (1997), "Defensive and Strategic Restructuring in Central and Eastern European Entreprises", Journal of Transforming Economies and Societies 3: 21-46.

[12] Ichino, Andrea and Giovanni Maggi (1999), "Work Environment and Individual Background: Explaining Regional Shirking Differentials in a Large Italian Firm", Quarterly Journal of Economics 115: 1057-90.

[13] Journal of Financial Economics (editorial) (1989), "Clinical Papers and Their Role in the Development of Financial Economics", 24: 3-6.

[14] Kalbfleish, J. D. and R. L. Prentice, 1980. The Statistical Analysis of Failure Time Data, New York: John Wiley\&Sons. 
[15] Kornai, Janos (1992), The Socialist System - The Political Economy of Communism, Princeton University Press.

[16] Lazear, Edward (1992), "The Job as a Concept", in Performance Measurement, Evaluation, and Incentives, ed. William J. Bruns, Boston: Harvard Business School Press, pp. 183-215.

[17] Lazear, Edward (2000), "Performance Pay and Productivity", American Economic Review 90: 1346-61.

[18] Seltzer, Andre, and David Merrett (2000): "Personnel Policies at the Union Bank of Australia: Evidence form the 1888-1900 Entry Cohorts", Journal of Labor Economics 18: 573-613.

[19] Treble, John, Tim Barmby, Sarah Bridges, and Edwin van Gameren (2001): "The Internal Economics of The Firm: Further Evidence From Personnel Data", Labour Economics 8: 531-552.

[20] Van den Berg, Gerard (2001): "Duration Models: Specification, Identification, and Multiple Durations, in: J.J. Heckman and E. Leamer, eds. Handbook of Econometrics, Volume V, North-Holland, Amsterdam.

[21] Woodruff, David (2004): "Property Rights in Context: Privatization's Legacy for Corporate Legality in Poland and Russia," Studies in Comparative International Development 38: 82-108. 